\title{
Factors Affecting Sugar Accumulation and Fluxes in Warm- and Cool-Season Forages Grown in a Silvopastoral System
}

\author{
Valens Niyigena ${ }^{1}$, Amanda J. Ashworth ${ }^{2, *} \mathbb{D}$, Christine Nieman ${ }^{3}{ }^{\mathbb{D}}$, Mohan Acharya ${ }^{1}$, Kenneth P. Coffey ${ }^{1}$, \\ Dirk Philipp ${ }^{1}$, Lillian Meadors ${ }^{1}$ and Thomas J. Sauer ${ }^{4}$
}

1 Department of Animal Science, Division of Agriculture, University of Arkansas, Fayetteville, AR 72701, USA; valens.niyigena@aamu.edu (V.N.); macharya@uark.edu (M.A.); kcoffey@uark.edu (K.P.C.); dphilipp@uark.edu (D.P.); lfmeador@uark.edu (L.M.)

2 Poultry Production and Product Safety Research Unit, Agricultural Research Service, United States Department of Agriculture, Fayetteville, AR 72701, USA

3 Dale Bumpers Small Farms Research Center, Agricultural Research Service, United States Department of Agriculture, Booneville, AR 72927, USA; christine.c.nieman@usda.gov

4 National Laboratory for Agriculture and the Environment, Agricultural Research Service, United States Department of Agriculture, Ames, IA 50011, USA; tom.sauer@usda.gov

* Correspondence: Amanda.Ashworth@usda.gov

check for updates

Citation: Niyigena, V.; Ashworth, A.J.; Nieman, C.; Acharya, M.; Coffey, K.P.; Philipp, D.; Meadors, L.; Sauer,

T.J. Factors Affecting Sugar

Accumulation and Fluxes in Warmand Cool-Season Forages Grown in a Silvopastoral System. Agronomy 2021, 11, 354. https://doi.org/10.3390/ agronomy11020354

Academic Editor: Juan J. Villalba and Jennifer Mac-Adam

Received: 25 January 2021

Accepted: 14 February 2021

Published: 16 February 2021

Publisher's Note: MDPI stays neutral with regard to jurisdictional claims in published maps and institutional affiliations.

Copyright: (C) 2021 by the authors Licensee MDPI, Basel, Switzerland. This article is an open access article distributed under the terms and conditions of the Creative Commons Attribution (CC BY) license (https:// creativecommons.org/licenses/by/ $4.0 /)$.

\begin{abstract}
Forage management and environmental conditions affect water soluble carbohydrate (WSC) storage, and, in turn, influence ruminant forage utilization in silvopastoral systems. The objective was to determine effects of four dependent variables: forage species [(non-native, $\mathrm{C}_{3}$ (orchardgrass (Dactylis glomerata L.)) and native $\mathrm{C}_{4}$ mix (8:1:1 big bluestem (Andropogon gerardii Vitman), little bluestem (Schizachyrium scoparium Michx. Nash) and indiangrass (Sorghastrum nutans L.))]; fertility (poultry litter and an unfertilized control); forage sampling date (mid-May, late-May, early-June, mid-June, and late-June); and hour of day (0800, 1100, 1400, and $1700 \mathrm{~h}$ ) on WSC accumulation in a silvopasture. Concentrations of WSC $\left(\mathrm{g} \mathrm{kg} \mathrm{DM}^{-1}\right)$ were greater $(p \leq 0.05)$ for $\mathrm{C}_{3}$ forages, with poultry litter not impacting WSC accumulation. Overall, WSC was greatest in mid-June, with the lowest WSC concentration observed at 0800 compared to 1100,1400 , and $1700 \mathrm{~h}(p \leq 0.05)$. Therefore, harvesting forages later in the day resulted in greater WSC. A stepwise regression model indicated acid detergent fiber, ash, and forage $P$ concentration were the best predictors $\left(R_{2}=0.85, p \leq 0.05\right)$ of forage WSC. These results may be useful in future studies aimed at explaining diurnal cattle grazing preference and optimum forage harvest timing in silvopastoral systems.
\end{abstract}

Keywords: water soluble carbohydrates; forage species; forage quality; correlation analysis; poultry litter; and diurnal changes

\section{Introduction}

In silvopastures, or the integration of trees and livestock in one system, appropriate management of trees and pasture is critical to ensure complementary productivity. Forage management is particularly important for increasing forage nutrient composition and ensuring high forage utilization by grazing animals. Typically, non-structural carbohydrates, including water soluble carbohydrate (WSC), are not routinely measured in grazing experiments. However, cattle preference and intake likely have strong relationships with WSC [1-5], sometimes even more so than neutral detergent fiber (NDF) [5]. Therefore, investigations into potential factors affecting WSC concentration in forages, such as forage species, fertilization, and seasonal and diurnal variations are necessary to better understand forage utilization by grazing livestock in silvopasture systems.

Integrating both cool- and warm-season forages in silvopastoral systems may be advantageous to livestock producers because of the contrasting seasonal growth patterns. $\mathrm{C}_{3}$ grasses reportedly have greater concentrations of WSC than $\mathrm{C}_{4}$; however, WSC in both 
$\mathrm{C}_{3}$ and $\mathrm{C}_{4}$ species, are reportedly affected by various factors, including soil fertility [6]. Applications of poultry litter on pastures increases forage nutritive values, especially concentrations of $\mathrm{N}$ and $\mathrm{P}$ [7-9]. Although, synthetic $\mathrm{N}$ fertilizers may reportedly reduce WSC concentration [10,11], poultry litter impacts on WSC are widely unknown.

Water soluble carbohydrate levels in cool-season grasses can vary seasonally $[12,13]$ and diurnally $[6,12,14]$. Griggs et al. [14] observed a $35 \mathrm{~g} \mathrm{~kg}^{-1}$ dry matter (DM) increase in total WSC in orchardgrass (Dactylis glomerta L.) at 1900 compared to $0700 \mathrm{~h}$. Burner and Belesky [6] also observed increases in WSC as sampling hour progressed in orchardgrass at three different sites: one open pasture and two silvopasture sites. Similarly, in the warmseason forage, Melinis minutiflora, WSC increased by $10 \mathrm{~g} \mathrm{~kg}^{-1} \mathrm{DM}$, while starch increased $60 \mathrm{~g} \mathrm{~kg}^{-1} \mathrm{DM}$ between 0800 and $1800 \mathrm{~h} \mathrm{[13].} \mathrm{The} \mathrm{non-structural} \mathrm{carbohydrate} \mathrm{contents} \mathrm{of}$ switchgrass (Panicum virgatum L.) and eastern gamagrass (Tripsacum dactyloides L.) baleage increased 38\% when harvested at $1800 \mathrm{~h}$ rather than $0600 \mathrm{~h}$, which resulted in increased total dry matter intake by steers offered these baleages [15].

Variation in seasonal and diurnal WSC accumulation in cool-season forages has been well documented; however, less information exists for $C_{4}$ species in comparison with $C_{3}$ species, with or without poultry litter fertilization. Consequently, the impact of these factors on WSC accumulation in forages grown in an integrated agroforestry system in the midSouth is not well understood. In order to advance our understanding of factors affecting WSC accumulation and fluxes in forages, this study aims to evaluate: (i) differences in WSC accumulation in $C_{3}$ and $C_{4}$ grasses; (ii) how fertility (poultry litter) impacts forage WSC; (iii) diurnal and seasonal fluctuations for $C_{3}$ and $C_{4}$ forages, fertilized and un-fertilized; and (iv) correlations between forage nutrient content parameters and WSC concentrations in a silvopastoral system. Authors hypothesize that $C_{3}$ forages will have greater WSC (across all sampling dates), that diurnal and grazing-season fluxes will occur, and that poultry litter amendments will influence WSC accumulation.

\section{Materials and Methods}

This study was conducted on a 4.25-ha silvopastoral system located at the University of Arkansas Agricultural Research and Extension Center in Fayetteville, AR $\left(36.09^{\circ} \mathrm{N}\right.$, $\left.94.19^{\circ} \mathrm{W}\right)$. The site is in the Ozark Highlands, Major Land Resource Area 116A [16]. Previous site history and tree establishment is described by DeFauw et al. [17], Sauer et al. [18], and Thomas et al. [19]. Soil in most of the experimental area is mapped as Captina silt loam (fine-silty, siliceous, active, mesic Typic Fragiudults) with some Pickwick silt loam (fine-silty, mixed, semiactive, thermic Typic Paleudults) and small areas of Johnsburg silt loam (fine-silty, mixed, active, mesic Aquic Fragiudults), and Nixa cherty silt loam (loamy-skeletal, siliceous, active, mesic Glossic Fragiudults) [20].

Briefly, in 2000, fifteen rows of three tree species including Northern red oak (Quercus rubra L.), eastern black walnut (Juglans nigra L.), and pecan (Carya illinoinensis Wangenh. K. Koch) were oriented east-west at 15-m spacing between rows [18]. In 2014, the eastern black walnut trees were replaced with rows containing three species including: American sycamore (Plantanus occidentalis L.), cottonwood (Populus deltoides W. Bartram ex Marshall), and pitch/loblolly pine (Pinus rigida $\times$ Pinus taeda). Forage species treatments were established in the alleys between tree rows, including a cool-season species (orchardgrass (cv. Tekapo)), seeded fall 2015 at $17 \mathrm{~kg}$ pure live seed (PLS) ha ${ }^{-1}$ and a native warmseason mix [8:1:1 big bluestem (Andropogon gerardii Vitman), little bluestem (Schizachyrium scoparium (Michx. Nash)) and indiangrass (Sorghastrum nutans L.)], which was seeded in spring of 2016 at $10 \mathrm{~kg} \mathrm{PLS} \mathrm{ha}^{-1}$. Alleys or experimental units $(148 \times 15 \mathrm{~m})$ were planted with a Haybuster 107C no-till drill (DuraTech, Jamestown, ND, USA), with each alley being replicated thrice. Before establishment, Cornerstone ${ }^{\circledR}$ Plus (Westwego, LA, USA) (N-[phosphonomethyl] glycine) was used to kill existing vegetation at a $2.2 \mathrm{~kg} \mathrm{ha}^{-1}$ rate (41\% a.i.). After establishment, alleys were treated with Plateau ${ }^{\mathrm{TM}}$ (BASF, Fremont, CA, USA) (Ammonium salt of imazapic) at $0.28 \mathrm{~kg} \mathrm{ha}^{-1}$ rate (23.6\% a.i.). The site receives 
an average (30-year mean) annual precipitation of $1232 \mathrm{~mm}$ and has an average ambient temperature of $14.5^{\circ} \mathrm{C}$ [21].

\subsection{Treatment Implementation and Study Management}

Forage species were the whole plots and fertility split-plots, with three replications. Fertility (using locally sourced poultry litter) was applied to both forage treatments at a rate of $84 \mathrm{~kg} \mathrm{~N} \mathrm{ha}^{-1}$ on 21 March 2018, and on $12 \mathrm{April}^{2019}$ (4.94 Mg ha ${ }^{-1}$, fresh weight basis). Poultry litter used in 2018 was $19.8 \mathrm{~g} \mathrm{~kg}^{-1}, 5.8 \mathrm{~g} \mathrm{~kg}^{-1}, 10.2 \mathrm{~g} \mathrm{~kg}^{-1}$, and 6.2 for N, P, $\mathrm{K}$, and $\mathrm{pH}$, respectively, and $24.8 \mathrm{~g} \mathrm{~kg}^{-1}, 6.9 \mathrm{~g} \mathrm{~kg}^{-1}, 9.4 \mathrm{~g} \mathrm{~kg}^{-1}$ and 5.2 for $\mathrm{N}, \mathrm{P}, \mathrm{K}$, and $\mathrm{pH}$, respectively, in 2019 (Arkansas Diagnostic Laboratory, Fayetteville, AR, USA). Response to litter application was compared with an unfertilized control. Angus heifers (Bos taurus L.) grazed the site; stocking rates were maintained at 2.20 animal units (AU) ha ${ }^{-1}$ from 24 May to 6 July 2018, and 2.42 AU ha $^{-1}$ from 29 May to 11 July 2019. The animals had access to the entire area throughout the experiment. Weather variables were measured by a micro-meteorological weather station approximately $500 \mathrm{~m}$ from the experimental site.

\subsection{Sample Collection and Analysis}

Forage sampling for WSC occurred four times per year (mid-May, late-May, earlyJune, mid-June, and late-June). On each sampling date, 10 random samples (per treatment combination) were collected in a transect in the grazed alleys at four time points: 0800, 1100, 1400, and $1700 \mathrm{~h}$. These data were used to determine diurnal fluctuations in water soluble carbohydrate concentration $\left(\mathrm{g} \mathrm{kg} \mathrm{DM}^{-1}\right)$. These samples were gathered from ungrazed and undamaged fully emerged plants to minimize confounding effects from grazed tissue. If undamaged samples were not available, they were collected from enclosures. Specifically, $4 \mathrm{~m}^{2}$ enclosures were placed and secured in each alley center (per experimental unit to minimize shading effects) of each treatment combination (three replications total). Samples were collected on days with little to no cloud coverage. In addition, enclosures were removed at the end of each experimental year and placed in a random location the following year to minimize year affects. Plants were clipped to $4 \mathrm{~cm}$ above the soil and upon collection, samples were immediately placed on ice in a cooler prior to transporting to the laboratory. Once in the laboratory, samples were weighed and stored in $-20{ }^{\circ} \mathrm{C}$ before subsequent lyophilization. Samples were weighed upon removal from the freeze-dryer, and ground through a 1-mm screen using a Wiley Mill (Thomas Scientific, Swedesboro, NJ, USA).

In tandem with sampling for WSC, forage mass and nutritive samples were collected from within the aforementioned $4 \mathrm{~m}^{2}$ enclosures by clipping forage $\left(0.25 \mathrm{~m}^{2}\right) 4 \mathrm{~cm}$ above the soil surface. One sample was collected per date from within each enclosure $(n=3$ per species $\times$ fertility treatment combination) to correlate forage nutrient variables and WSC. Subsequently, forage sub-samples were dried at $60^{\circ} \mathrm{C}$ for $48 \mathrm{~h}$ and reweighed to determine moisture content for DM yield. After drying, samples were ground using a Wiley mini-mill (Thomas Scientific, Swedesboro, NJ, USA) to pass through a 1-mm screen. Total C and $\mathrm{N}$ were determined via high-temperature combustion using a VarioMax $\mathrm{C}$ : $\mathrm{N}$ analyzer (Elementar Americas, Mt. Laurel, NJ, USA) and crude protein (CP) was calculated by multiplying $\mathrm{N}$ by 6.25. Neutral detergent fiber, acid detergent fiber (ADF), and lignin were determined sequentially using an ANKOM 2000 Fiber Analyzer (ANKOM Technologies, Macedon, NY, USA) [22]. Hemicellulose was calculated as NDF minus ADF [22]. Ash concentration was determined by burning samples in a muffle furnace at $500{ }^{\circ} \mathrm{C}$ for $6 \mathrm{~h}$ (Method 942.05) [23]. Forage samples were digested with concentrated $\mathrm{HNO}_{3}$ and $\mathrm{H}_{2} \mathrm{O}_{2}$, and mineral elements were measured by inductively coupled plasma using a 5110 ICP-OES (Agilent, Santa Clara, CA, USA). In addition, plant heights (5 observations per species and fertility treatment per replicate) of un-grazed forage samples were recorded per sampling date.

The concentration of WSC was measured in forage samples using a calorimetric procedure as described by Dubois et al. [24]. Briefly, standards were prepared by mixing $0.1 \mathrm{~g}$ of dextrose with $250 \mathrm{~mL}$ distilled water. Then, $0.25 \mathrm{~g}$ of each forage sample was 
soaked in distilled water for $2 \mathrm{~h}$ and the solution was filtered. Samples and standards were transferred to glass tubes, and $0.133 \mathrm{~mL}$ of $0.90 \%(w t / w t)$ phenol and $5 \mathrm{~mL}$ of concentrated $\mathrm{H}_{2} \mathrm{SO}_{4}$ were added. Samples were then placed at room temperate for $10 \mathrm{~min}$ followed by incubation for $20 \mathrm{~min}$ in a water bath at $28^{\circ} \mathrm{C}$. Absorbance was measured on a spectrophotometer (SPECTRAmax 250, Molecular Products, Sunnyvale, CA, USA) set to a $490 \mathrm{~nm}$ wavelength. The WSC were reported on a $\mathrm{g} \mathrm{kg} \mathrm{DM}{ }^{-1}$ basis. The absorbance and concentrations of standards (ug sugar / $\mathrm{mL}$ solution) were used to build a scatter plot to get a regression equation from the trend line, the concentration of WSC standards was plotted as a function of absorbance. This relationship was then used to determine the concentrations of WSC in forage samples. Since dilution of samples was $0.25 \mathrm{~g}$ sample in $100 \mathrm{~mL}$ solution, the final concentration was calculated on an air-dry basis (Equation (1), as

$$
\begin{aligned}
& \text { g sugar / } \mathrm{kg} \text { sample DM }-1 \text { basis } \\
& =[(\text { ug sugar } / \mathrm{mL} \text { solution }) \\
& \times(100 \mathrm{~mL} \text { solution } / 0.25 \mathrm{~g} \text { sample weight/1000 })]
\end{aligned}
$$

\subsection{Analysis of Data and Model Development}

Analysis of variance (ANOVA) tests of explanatory variables including WSC, yield, and forage nutrient variables (ADF, NDF, lignin, ash, $C, N, C / N, C P$, and minerals) were performed using the MIXED procedure of SAS (SAS V9.3; SAS Inst., Cary, NC, USA) [25]. In each model, forage species, fertility (poultry litter and the control), and sample date were considered fixed effects, whereas sampling time within sampling date was considered a repeated measure. For the repeated measure, an autoregressive covariance was used and the denominator degrees of freedom for Type III F-test were adjusted with the Kenward-Roger method [26]. However, the -2 Log-likelihood did not change under the repeated-measure analysis (i.e., did not drop by at least 5 per covariance parameter) and the autoregressive correlation value (0.24) indicated a weak correlation among observations, so autoregressive covariance was removed. Thereafter, an additional model, which included sampling timing within sampling date was included as a fixed effect and plant height as a covariate was run using a mixed model analysis of variance (MMAOV). In all models, year and replication were random effects. When effects or interaction confluences were found, mean separations were performed using the SAS macro 'pdmix800' [27] with Fisher's least significant difference at a Type I error rate of less than or equal to 5\% [25].

A stepwise regression analysis was also performed on WSC and forage nutrient parameters to evaluate what forage nutrient parameters, if any, are linked to WSC in efforts to identify if any forage quality trait could be used as a proxy for time-consuming WSC analyses.

\section{Results and Discussion}

\subsection{Diurnal and Temporal Variations of WSC Based on Treatments}

A four-way interaction (forage species $\left(C_{3}\right.$ and $\left.C_{4}\right) \times$ poultry litter fertility treatment (fertilized with poultry litter and a control) $\times$ date (mid-May, late-May, mid-June, and lateJune $) \times$ sampling time $(800,1100,1400$, and $1700 \mathrm{~h}))$ was not observed for WSC $(p \geq 0.05$; Table 1$)$. However, a date $\times$ sampling time interaction was detected $(p \leq 0.05)$. The greatest $(p \leq 0.05)$ concentration of WSC $\left(128 \mathrm{~g} \mathrm{~kg} \mathrm{DM}^{-1}\right)$ was observed mid-June at the $1100 \mathrm{~h}$ sampling time (Figure 1). These values, however, were not different $(p \geq 0.05)$ from forages harvested at $1400 \mathrm{~h}$ in mid-May, late May, and mid-June, and forages harvested at $1700 \mathrm{~h}$ in late-May and mid-June. Generally, WSC concentrations were lowest when harvested late-June and at $800 \mathrm{~h}$ across all dates and sampling time points. 
Table 1. Analysis of variance of water-soluble carbohydrates from 2018 and 2019 (analyzed across years as there were no year effect; $p \geq 0.05)$ based on two forage species types $\left(\mathrm{C}_{4}\right.$ : native grass mix; and $C_{3}$ : non-native, orchardgrass), fertility (with and without poultry litter), dates (late-May, early June, mid-June, and late-June), and diurnal time points $(800,1100,1400$, and $1700 \mathrm{~h}$ ) in a silvopastoral system in Fayetteville, AR, USA.

\begin{tabular}{cccc}
\hline Effect & Num. DF $^{+}$ & $\boldsymbol{F}$ Value & $p \geq \mathbf{F}^{++}$ \\
\hline Species & 1 & 39.39 & $\leq 0.0001$ \\
Fertility & 1 & 2.07 & 0.1515 \\
Species $\times$ Fertility & 1 & 0.52 & 0.4711 \\
Date & 3 & 2.87 & 0.0365 \\
Date $\times$ Species & 3 & 1.19 & 0.3140 \\
Date $\times$ Fertility & 3 & 0.32 & 0.8080 \\
Date $\times$ Species $\times$ Fertility & 3 & 0.17 & 0.9147 \\
Sampling time & 3 & 5.78 & 0.0007 \\
Species $\times$ Sampling time & 3 & 0.76 & 0.5178 \\
Fertility $\times$ Sampling time & 3 & 0.10 & 0.9593 \\
Species $\times$ Fertility $\times$ Sampling time & 3 & 0.06 & 0.9797 \\
Date $\times$ Sampling time & 9 & 2.24 & 0.0193 \\
Date $\times$ Species $\times$ Sampling time & 9 & 0.38 & 0.9458 \\
Date $\times$ Fertility $\times$ Sampling time & 9 & 0.04 & 1.0000 \\
Date $\times$ Species $\times$ Fertility $\times$ Sampling time & 9 & 0.05 & 1.0000 \\
\hline
\end{tabular}

${ }^{\dagger}$ Num. DF = numerator degree of freedom, Den. DF $=$ denominator degree of freedom; ${ }^{+\dagger}$ ANOVA probability levels significant at $p \leq 0.05$.

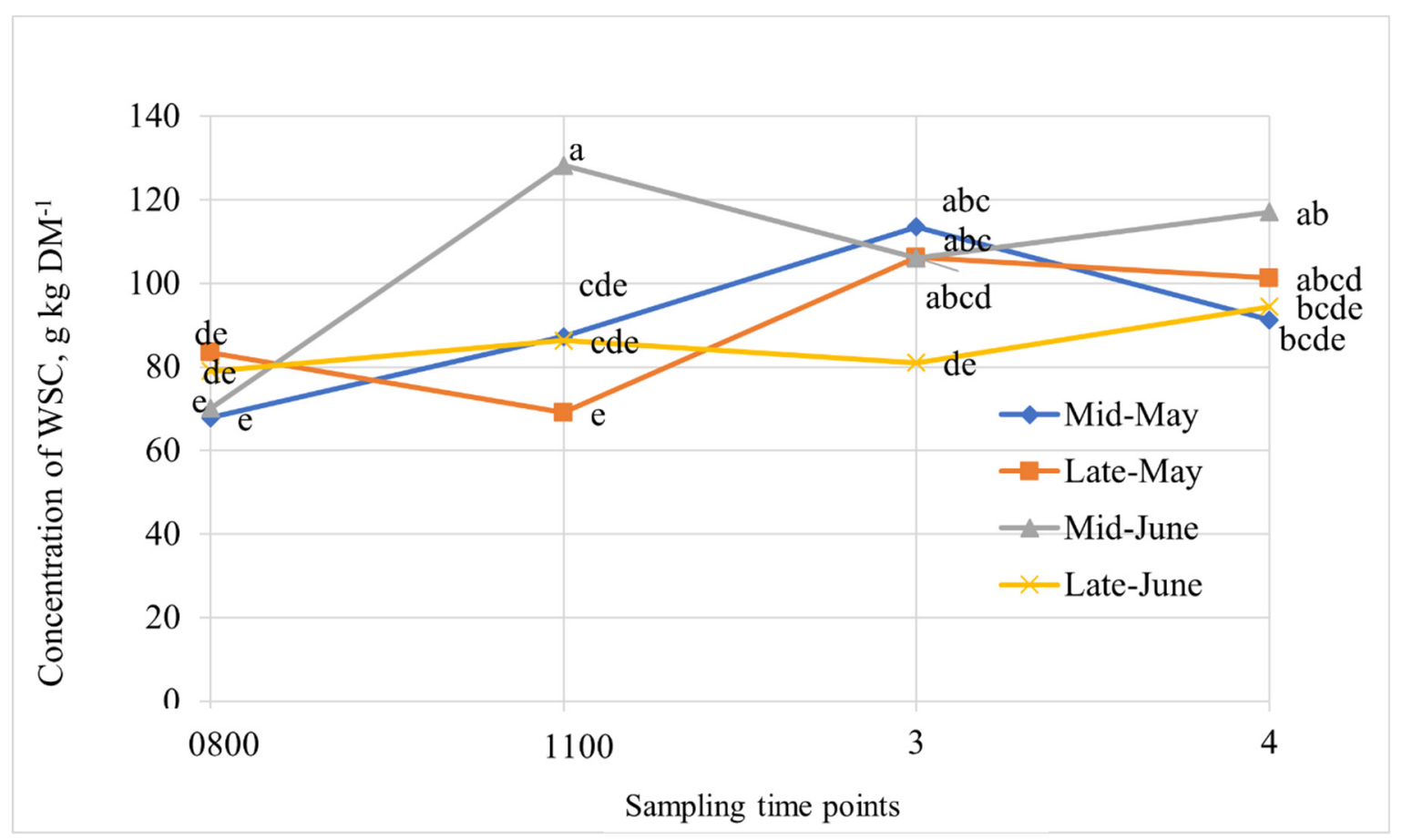

Figure 1. Diurnal changes in water soluble carbohydrates concentration $\left(\mathrm{g} \mathrm{kg} \mathrm{DM}^{-1}\right)$ due to sampling time points $(800,1100$, 1400 , and $1700 \mathrm{~h}$ ) within multiple sampling dates (mid-May, late-May, early June, mid-June, and late-June) in a silvopastoral system. Different letters indicate a significant difference at $p \leq 0.05$ between interactive sample date $\times$ sampling time means $(\mathrm{DM}=$ dry matter, WSC $=$ water soluble carbohydrates $)$.

The interaction between date and sampling time as likely owing to plant maturity and diurnal WSC accumulation. From mid-May until mid-June, the $\mathrm{C}_{3}$ was developing seedheads, whereas $\mathrm{C}_{4}$ grasses were in a state of vegetative growth with a greater biomass contribution from leafy components [28]. As grasses mature, an increase in cell wall 
components reduces the concentration of WSC [29]. Since plant leaves are the main site for photosynthesis, a decrease in leaf mass and surface area may decrease photosynthetic rates and carbohydrate storage [30].

Daily fluctuations in WSC generally suggest lower concentration in mornings than in later hours of the day. Our results suggest a WSC increase of $26 \mathrm{~g} \mathrm{~kg} \mathrm{DM}^{-1}$ from 800 to $1700 \mathrm{~h}$. Through photosynthesis, plants utilize sunlight to convert carbon dioxide and water into carbohydrates [31] and WSC typically increases during the day as a result of an imbalance between photosynthesis and respiration [32]. During the night, plants consume WSC during respiration, resulting in reduced levels of WSC in the morning [33]. Similarly, other studies found a comparable pattern, wherein the concentration of WSC were 10\% greater in red (Trifolium pratense L.) and white clover (Trifolium repens $\mathrm{L}$.) in the afternoon (1500-1600 h) than in morning (800-900 h) [12]. In addition, Griggs et al. [14] observed $35 \mathrm{~g} \mathrm{~kg} \mathrm{DM}^{-1}$ increase in total soluble carbohydrates in orchardgrass at 1900 compared to $700 \mathrm{~h}$. Similarly, Cajarville et al. [34] reported a linear increase in WSC for cool-season forages when harvested at different time intervals $(900,1300$, and $1700 \mathrm{~h}$ ). Although not directly measured, photosynthetically active radiation and solar radiation intensity may influence WSC accumulation and diurnal patterns in silvopastoral systems.

Unexpectedly, applications of poultry litter did not affect $(p=0.15)$ WSC accumulation across forage species, sampling dates, or sampling times (Table 1); therefore, this hypothesis was rejected. Likewise, interactions of the other main effects and the poultry litter treatment did not affect $(p=0.47)$ WSC concentrations. Clark et al. [35] found WSC concentrations were not different in bermudagrass (Cynodon dactylon L.) hay following either a no poultry litter application, poultry litter application immediately after harvest, or poultry litter applied $14 \mathrm{~d}$ post-harvest. However, in other studies, applications of inorganic-N reduced the concentrations of WSC in forages [10,11]. Likely, poultry litter applications did not have an impact on WSC in this study owing to poultry litter releasing N more slowly compared to inorganic sources of N. Further, shading could explain the lack of response to fertilization, owing to reduced photosynthetically active radiation and subsequently lesser WSC production in silvopastures.

Forage WSC was $32 \mathrm{~g} \mathrm{~kg} \mathrm{DM}^{-1}$ greater $(p \leq 0.05)$ in $C_{3}$ compared to $C_{4}$ grasses (Table 2). The presence of mesophyll in $\mathrm{C}_{3}$ plants allows them to store more WSC, while $\mathrm{C}_{4}$ have greater fibrous plant material in bundle sheaths [10]. Effectively, a greater ratio of leaves to stems results in greater WSC, but this ratio is lower in warm than in cool-season grasses [36]. Seasonal variations also affect the usage and storage of WSC in both $C_{3}$ and $C_{4}$ grasses [37]; however, warm-season grasses generally accumulate less non-structural carbohydrates than cool-season grasses [38]. Cool-season grasses produce fructan and greater total non-structural carbohydrates compared to warm-season forages and legumes [39,40]. Differences in seasonal shading may have also played a role in WSC storage. For example, the position of the sun drives radiation intensity, thus ultimately affecting photosynthesis rates. Consequently, further research is needed to better understand relative reductions in WSC and other forge nutrient parameters due to shading in silvopasture systems. Future work should evaluate WSC storage of orchardgrass and the native big bluestem mix in an open pasture, without the presence of trees, as well as evaluate linkages to WSC and diameter at breast height per tree species. 
Table 2. Average concentration of water-soluble carbohydrates by forage species $\left(\mathrm{C}_{4}\right.$ : native grass mix; and $\mathrm{C}_{3}$ : non-native, orchardgrass) and fertility (with and without poultry litter) from 2018-2019 in a silvopasture system. The concentrations were measured in forage samples collected on four different sampling dates (late-May, early-June, mid-June, and late-June) and diurnal time points (800, 1100,1400 , and $1700 \mathrm{~h}$ ).

\begin{tabular}{ccc}
\hline Forage Species & Mean & Standard Error \\
\hline & $\mathrm{g} \mathrm{kg} \mathrm{DM}^{-1+}$ & \\
\hline Native grass & $76.4 \mathrm{~b}^{++}$ & 4.22 \\
Orchardgrass & $108.7 \mathrm{a}$ & 4.22 \\
\hline Fertility & $\mathrm{g} \mathrm{kg} \mathrm{DM}^{-1}$ & \\
\hline Fertilized & $96.2 \mathrm{a}$ & 4.22 \\
Non-Fertilized & $88.7 \mathrm{a}$ & 4.22 \\
\hline
\end{tabular}

${ }^{\dagger} \mathrm{DM}=$ dry matter; ${ }^{+\dagger}$ different letters following a mean indicate a significant difference at $p \leq 0.05$.

\subsection{Temporal Forage Quantity and Quality Based on Forage Species and Fertility}

The three-way (forage species $\times$ poultry litter fertility treatment $\times$ forage sampling date) interaction did not affect forage herbage mass ( $p=0.82$; Table 3$)$. However, there were two-way interactions $(p \leq 0.05)$ between forage species $\left(C_{3}\right.$ and $\left.C_{4}\right)$ and fertility, between forage species and sampling date, and between sampling date and fertility for forage mass. Fertilized orchardgrass yield was greater $(p \leq 0.05$; Table 4$)$ than unfertilized orchardgrass. Yield of $C_{4}$ grasses (native big bluestem mix) was intermediate, and not different ( $p \geq 0.05$ ) from that of the $C_{3}$ grass with or without poultry litter. In $C_{4}$ forage species, poultry litter applications did not increase yields ( $p \geq 0.05$, Table 4 ) as it did with the orchardgrass. Generally, greatest yields were observed with the native grass mix harvested in June (earlyJune, mid-June, late June) and orchardgrass harvested in early May. Yields were generally lowest from warm-season grasses harvested in May and orchardgrass harvested after early May. A study conducted by Lin et al. [41] evaluated shade effects on 30 different forages, with warm-season forages displaying decreases in forage DM when grown under shade regardless of the season, while cool-season forage species exhibited more shade tolerance when grown during the summer. Therefore, warm-season yields may have been reduced owing to tree-induced shade. Peak yields for orchardgrass are widely reported to occur in May in the Southeast [42].

Table 3. Analysis of variance of yield from 2018 and 2019 (analyzed across two years, as there were no year effects; $p \geq 0.05)$ based on two forage species $\left(C_{4}\right.$ : native grass mix; and $C_{3}$ : non-native, orchardgrass), fertility (with and without poultry litter), dates (early-May, late-May, early-June, mid-June, and late-June) in a silvopastoral system in Fayetteville, AR.

\begin{tabular}{cccc}
\hline Effect & Num. DF & F Value & Pr $\geq \mathbf{F}^{++}$ \\
\hline Species & 1 & 0.23 & 0.6498 \\
Fertility & 1 & 9.91 & 0.0019 \\
Species $\times$ Fertility & 1 & 6.69 & 0.0105 \\
Date & 4 & 2.89 & 0.0236 \\
Date $\times$ Species & 4 & 3.74 & 0.0060 \\
Date $\times$ Fertility & 4 & 2.86 & 0.0250 \\
Date $\times$ Species $\times$ Fertility & 4 & 0.38 & 0.8243 \\
\hline
\end{tabular}

${ }^{\dagger}$ Num. DF $=$ numerator degree of freedom, Den. DF $=$ denominator degree of freedom, ${ }^{+\dagger}$ ANOVA probability levels significant at $p \leq 0.05$. 
Table 4. Average forage mass based on the two-way interaction of forage species $\left(\mathrm{C}_{4}\right.$ : native grass mix; and $\mathrm{C}_{3}$ : non-native, orchardgrass) $\times$ fertility (fertilized with poultry litter and without) as well as the two-way interaction of forage species $\times$ sampling date (early-May, late-May, early-June, mid-June, and late-June).

\begin{tabular}{|c|c|c|}
\hline Species & Fertility & Species $\times$ Fertility ${ }^{\dagger}$ \\
\hline & & $\mathrm{Mg} \mathrm{ha}^{-1}$ \\
\hline Native grass & Poultry litter & $2.24 \mathrm{ab}$ \\
\hline Native grass & Control & $2.13 \mathrm{ab}$ \\
\hline Orchardgrass & Poultry litter & $2.60 \mathrm{a}$ \\
\hline Orchardgrass & Control & $1.53 \mathrm{~b}$ \\
\hline \multirow[t]{2}{*}{ Species } & Date & Species $\times$ Date \\
\hline & & $\mathrm{Mg} \mathrm{ha}^{-1}$ \\
\hline Native grass & early-May & $1.14 \mathrm{~d}$ \\
\hline Native grass & late-May & $1.75 \mathrm{~d}$ \\
\hline Native grass & early-June & $2.52 \mathrm{abc}$ \\
\hline Native grass & mid-June & $2.97 \mathrm{a}$ \\
\hline Native grass & late-June & $2.55 \mathrm{abc}$ \\
\hline Orchardgrass & early-May & $2.51 \mathrm{ab}$ \\
\hline Orchardgrass & late-May & $1.80 \mathrm{~cd}$ \\
\hline Orchardgrass & early-June & $2.08 \mathrm{bcd}$ \\
\hline Orchardgrass & mid-June & $1.89 \mathrm{~cd}$ \\
\hline Orchardgrass & late-June & $2.04 \mathrm{bcd}$ \\
\hline
\end{tabular}

${ }^{\dagger}$ Different letters indicate a significant difference at $p \leq 0.05$ within a given column.

There were no three-way interactions $(p \geq 0.05)$ among forage species, fertility treatment, and forage sampling date for forage quality measurements. Forage quality parameters including NDF, ADF, lignin, ash, $\mathrm{N}$, and mineral concentration $(\mathrm{K}, \mathrm{P}$, and $\mathrm{Mg}$ ) were affected by sampling date $(p \leq 0.05$, Table 5$)$ but not by sampling date $\times$ forage species $(p \geq 0.05)$. Neutral detergent fiber concentrations were lowest ( $p \leq 0.05$; Table 5$)$ early May, with fiber contents increasing over the grazing-season. Concentrations of ADF followed a similar pattern through mid-June, but then declined sharply late-June. Crude protein was greater ( $p \leq 0.05$, Table 5 ) in less mature forage (e.g., early-May), regardless of photosynthetic pathway. Increasing maturity resulted in lower concentrations of non-structural carbohydrates and greater concentrations of cell wall constituents. Waramit et al. [43]) reported that delaying the harvesting date increased cellulose, lignin, and C concentrations, but decreased ash and $\mathrm{N}$ concentrations in different species of native grasses (big bluestem, eastern gamagrass, indiangrass, and switchgrass).

The lowest ( $p \leq 0.05$, Table 5) concentrations of $\mathrm{K}$ and P occurred mid-June. The decrease in $\mathrm{K}$ and $\mathrm{P}$ in forages was likely related to forage maturity [44,45]. In addition, minerals are more concentrated in leaves than in stems, and the ratio of leaves to stem decreases as plant matures, which in turn can further reduce forage mineral contents [46]. Further, in the present study, Mehlich 3 soil test $\mathrm{P}$ ranged from 17 to $64 \mathrm{mg} \mathrm{kg}^{-1}$ (data not shown; DNS), and the cool-season grass had a greater response to $\mathrm{P}$ applications via poultry litter than warm-season grasses. However, warm-season grasses have been shown to utilize soil $\mathrm{P}$ more efficiently, resulting in 3 times greater yield than cool-season grasses grown on a soil with low $\left(5 \mathrm{mg} \mathrm{kg}^{-1}\right) \mathrm{P}$ concentration [47].

Forage species affected mineral concentrations with greater $(p \leq 0.05$, Table 5$) \mathrm{K}, \mathrm{P}$, and $\mathrm{Mg}$ in orchardgrass compared to the warm-season grass mixture. Others reported that coolseason grasses contain greater $\mathrm{P}$ and lower $\mathrm{Mg}$ compared to warm-season forage [48,49]. Concentrations of NDF, ADF, lignin, ash, and hemicellulose, $\mathrm{C}, \mathrm{N}$, and $\mathrm{C} / \mathrm{N}$ were not affected by forage species $(p \geq 0.05$, Table 5$)$. 
Table 5. Variation in forage nutritive value measurements and selected macromineral concentrations by date (early-May, late-May, early-June, mid-June, and late-June) and by forage species $\mathrm{C}_{3}$ (non-native, orchardgrass) and $\mathrm{C}_{4}$ (native grass mix) forages grown in a silvopastoral system with and without poultry litter fertilization.

\begin{tabular}{|c|c|c|c|c|c|c|c|c|c|c|c|}
\hline Date & NDF ${ }^{++}$ & ADF & Lignin & Ash & C & $\mathbf{N}$ & $\mathrm{CP}$ & $\mathrm{C}: \mathbf{N}$ & $\mathbf{K}$ & $\mathbf{P}$ & Mg \\
\hline & & & \multicolumn{6}{|c|}{$-\mathrm{g} \mathrm{kg}^{-1} \mathrm{DM}$} & \multicolumn{3}{|c|}{$-\mathrm{g} \mathrm{kg}^{-1}$} \\
\hline Early-May ${ }^{\dagger}$ & $557 \mathrm{c} \ddagger$ & $336 \mathrm{bc}$ & $58 \mathrm{ab}$ & $11 \mathrm{ab}$ & $441 \mathrm{a}$ & $22 \mathrm{c}$ & $138 \mathrm{a}$ & $210 c$ & $16.538 \mathrm{a}$ & $3.117 \mathrm{ab}$ & $1.181 \mathrm{~d}$ \\
\hline Late-May & $612 b$ & $351 \mathrm{ab}$ & $48 \mathrm{c}$ & $8 \mathrm{~b}$ & $447 \mathrm{a}$ & $17 \mathrm{~b}$ & $110 \mathrm{~b}$ & $262 b$ & $15.220 \mathrm{ab}$ & $3.105 \mathrm{ab}$ & $1.425 \mathrm{c}$ \\
\hline Early-June & $630 a b$ & $360 \mathrm{ab}$ & $57 \mathrm{a}$ & $16 \mathrm{a}$ & $446 \mathrm{a}$ & $16 \mathrm{a}$ & $100 \mathrm{c}$ & $290 \mathrm{a}$ & $14.285 \mathrm{ab}$ & $3.074 \mathrm{ab}$ & $1.540 \mathrm{c}$ \\
\hline Mid-June & $633 \mathrm{a}$ & $363 \mathrm{a}$ & $49 \mathrm{bc}$ & $9 \mathrm{~b}$ & $448 \mathrm{a}$ & $15 \mathrm{a}$ & $95 c$ & $305 \mathrm{a}$ & $13.489 \mathrm{~b}$ & $2.995 \mathrm{~b}$ & $1.722 \mathrm{~b}$ \\
\hline $\begin{array}{l}\text { Late-June } \\
\text { Forage } \\
\text { species }\end{array}$ & $614 a b$ & $317 \mathrm{c}$ & $51 \mathrm{abc}$ & $9 b$ & $444 \mathrm{a}$ & $16 \mathrm{ab}$ & $100 \mathrm{bc}$ & $286 a b$ & $14.335 \mathrm{ab}$ & $3.501 \mathrm{a}$ & $2.047 \mathrm{a}$ \\
\hline Native grass & $615 \mathrm{a}^{+}$ & $345 a$ & $50 a$ & $10 \mathrm{a}$ & $450 \mathrm{a}$ & $17 \mathrm{a}$ & $106 a$ & $280 a$ & $12.509 \mathrm{~b}$ & $2.713 \mathrm{~b}$ & $1.370 \mathrm{~b}$ \\
\hline Orchardgrass & $603 a$ & $345 a$ & $55 \mathrm{a}$ & $12 \mathrm{a}$ & $442 \mathrm{a}$ & $17 \mathrm{a}$ & $111 \mathrm{a}$ & $262 a$ & $17.038 \mathrm{a}$ & $3.604 \mathrm{a}$ & $1.796 \mathrm{a}$ \\
\hline
\end{tabular}

${ }^{\dagger}$ Different letters indicate a significant difference at $p \leq 0.05$ within a given column. Data were combined across forage species because of the failure to detect a forage species by harvest date interaction $(p \geq 0.05) .{ }^{++} \mathrm{NDF}=$ neutral detergent fiber, $\mathrm{ADF}=$ acid detergent fiber, $\mathrm{C}=$ carbon, $\mathrm{N}=$ nitrogen, $\mathrm{CP}=$ crude protein, $\mathrm{K}=$ potassium, $\mathrm{P}=$ phosphorus, $\mathrm{Mg}=$ magnesium. ${ }^{\ddagger}$ Different letters within a given column indicate a significant difference at $p \leq 0.05$.

\subsection{Correlation between Water Soluble Carbohydrates and Forage Quality Measurements}

Forage WSC was positively correlated with $\mathrm{K}, \mathrm{P}, \mathrm{Mn}$, and yield $(p \leq 0.05 ; r \geq 0.61$; Table 6) and negatively correlated with forage height ( $p \leq 0.05 ; r \geq-0.25 ; \mathrm{DNS})$. When environmental parameters such as temperature and wind speed were included in the correlation analysis, there was a positive correlation between WSC and time of the day $(p \leq 0.05, r=0.2)$, but no correlation with temperature and humidity ( $p \geq 0.05$; DNS).

Table 6. Pearson correlation coefficients between forage nutritive parameters from two forage species $\left(C_{4}\right.$ : native grass mix; and $C_{3}$ : non-native, orchardgrass) grown in a silvopastoral system with and without poultry litter application and harvested on multiple dates (early-May, late-May, early-June, mid-June, and late-June).

\begin{tabular}{|c|c|c|c|c|c|c|c|c|c|c|c|c|c|}
\hline Parameter & & $\mathrm{K}^{t+}$ & $\mathrm{Mg}$ & $\mathbf{P}$ & Mn & NDF & ADF & Lignin & Ash & $\mathrm{C}$ & $\mathbf{N}$ & Yield & WSC \\
\hline \multirow[t]{2}{*}{ K } & $\begin{array}{l}r \\
+\end{array}$ & 1 & & & & & & & & & & & \\
\hline & $p$-value & & & & & & & & & & & & \\
\hline \multirow[t]{2}{*}{$\mathrm{Mg}$} & $r$ & 0.301 & 1 & & & & & & & & & & \\
\hline & $p$-value & 0.197 & & & & & & & & & & & \\
\hline \multirow[t]{2}{*}{$\mathrm{P}$} & $r$ & 0.817 & 0.647 & 1 & & & & & & & & & \\
\hline & $p$-value & $\leq 0.0001$ & 0.002 & & & & & & & & & & \\
\hline \multirow[t]{2}{*}{$\mathrm{Mn}$} & $r$ & 0.541 & 0.336 & 0.371 & 1 & & & & & & & & \\
\hline & $p$-value & 0.013 & 0.141 & 0.106 & & & & & & & & & \\
\hline \multirow[t]{2}{*}{$\mathrm{NDF}$} & $r$ & -0.515 & 0.336 & -0.237 & 0.085 & 1 & & & & & & & \\
\hline & $p$-value & 0.019 & 0.144 & 0.313 & 0.718 & & & & & & & & \\
\hline \multirow[t]{2}{*}{$\mathrm{ADF}$} & $r$ & -0.281 & -0.197 & -0.237 & 0.595 & 0.357 & 1 & & & & & & \\
\hline & $p$-value & 0.906 & 0.405 & 0.313 & 0.005 & 0.121 & & & & & & & \\
\hline \multirow[t]{2}{*}{ Lignin } & $r$ & 0.365 & -0.070 & 0.261 & 0.021 & -0.464 & -0.067 & 1 & & & & & \\
\hline & $p$-value & 0.113 & 0.766 & 0.266 & 0.927 & 0.039 & 0.7786 & & & & & & \\
\hline \multirow[t]{2}{*}{ Ash } & $r$ & 0.234 & 0.022 & 0.043 & 0.243 & 0.129 & 0.290 & 0.244 & 1 & & & & \\
\hline & $p$-value & 0.319 & 0.925 & 0.854 & 0.301 & 0.586 & 0.214 & 0.299 & & & & & \\
\hline \multirow[t]{2}{*}{$\mathrm{C}$} & $r$ & 0.454 & -0.467 & 0.205 & -0.124 & -0.849 & -0.342 & 0.390 & -0.060 & 1 & & & \\
\hline & $p$-value & 0.044 & 0.037 & 0.384 & 0.599 & $\leq 0.01$ & 0.139 & 0.088 & 0.800 & & & & \\
\hline \multirow[t]{2}{*}{$\mathrm{N}$} & $r$ & -0518 & 0.406 & -0.290 & 0.127 & $\overline{0} .837$ & 0.369 & -0.411 & 0.063 & -0976 & 1 & & \\
\hline & $p$-value & 0.019 & 0.074 & 0.214 & 0.592 & $\leq 0.001$ & 0.109 & 0.071 & 0.790 & $\leq 0.001$ & & & \\
\hline \multirow[t]{2}{*}{ Yield } & $r$ & 1.000 & 0.301 & 0.817 & 0.541 & -0.515 & -0.028 & 0.365 & 0.234 & 0.454 & -0.518 & 1 & \\
\hline & $p$-value & $\leq 0.001$ & 0.197 & $\leq 0.001$ & 0.013 & 0.019 & 0.904 & 0.113 & 0.319 & 0.044 & 0.019 & & \\
\hline \multirow[t]{2}{*}{ WSC } & $r$ & 0.777 & 0.399 & $\overline{0} .7184$ & 0.606 & -0.145 & 0.249 & 0.361 & 0.105 & -0.151 & 0.105 & 0.772 & 1 \\
\hline & $p$-value & $\leq 0.001$ & 0.081 & $\leq 0.001$ & 0.004 & 0.539 & 0.289 & 0.117 & 0.657 & 0.522 & 0.657 & $\leq 0.001$ & \\
\hline
\end{tabular}

${ }^{+}$Bolded letters indicate significant differences at $p \leq 0.05 .{ }^{{ }^{+\dagger}} \mathrm{K}=$ potassium, $\mathrm{Mg}=$ magnesium, Mn = manganese, NDF = neutral detergent fiber, $\mathrm{ADF}=$ acid detergent fiber, $\mathrm{C}=$ carbon, $\mathrm{N}=$ nitrogen, $\mathrm{P}=$ phosphorus, WSC $=$ water soluble carbohydrates.

Plant K concentration declines with maturity [50] as does WSC [51]. However, the positive relationship between WSC and $\mathrm{K}$ in this study were not consistent with published results of Wang et al. [52], in which $\mathrm{K}$ increased by $14 \%$ as WSC in forage decreased by 
$10 \mathrm{~g} \mathrm{~kg}^{-1} \mathrm{DM}$. Ash and WSC are both constituents of non-structural fractions within the plant and can explain the positive correlation in this study. Jafari [23] conducted a review of 13 studies on correlations between WSC and DM yield; the results were inconsistent and suggested that DM yield and WSC were independent or showed a weak positive correlation. However, in this study there was a significantly positive relationship between WSC and yield.

In this study, when all forage quality and mineral concentrations were included in a stepwise regression analysis to build a model to predict the WSC in forage, 85\% of variability in WSC concentration in cool and warm-season forages can be explained by ADF, ash, and P content (Table 7). Concentrations of WSC $\left(\mathrm{g} \mathrm{kg} \mathrm{DM}^{-1}\right)$ are estimated in Equation (2):

$$
W S C=-111.5+(31 \times A D F)+(163 \times a s h)+(0.000024 \times P)
$$

where ADF, ash, and $\mathrm{P}$ are expressed as $\mathrm{g} \mathrm{kg}^{-1}$.

Table 7. Stepwise regression analysis between different forage nutritive components and watersoluble carbohydrate in two forage species grown in a silvopastoral system.

\begin{tabular}{cccc}
\hline Parameter & Coefficient & $p$ Value ${ }^{\dagger}$ & $R$ Square \\
\hline WSC $^{+\dagger}, \mathrm{g} \mathrm{kg} \mathrm{DM}^{-1}$ & & & \\
$\mathrm{Intercept}^{\mathrm{ADF}}\left(\mathrm{g} \mathrm{kg}^{-1}\right)$ & -111.5 & 0.01 & 0.85 \\
$\mathrm{Ash}\left(\mathrm{g} \mathrm{kg}^{-1}\right)$ & 31 & 0.04 & \\
$\mathrm{P}\left(\mathrm{g} \mathrm{kg}^{-1}\right)$ & 163 & $\leq 0.01$ & \\
\hline
\end{tabular}

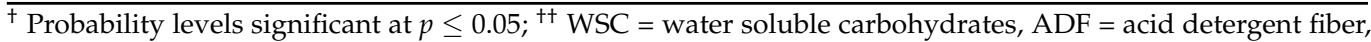
$\mathrm{P}=$ phosphorus.

Overall, accumulation of WSC in forage is an important factor for forage utilization by ruminants; however, the analysis of WSC in forage is time consuming. Therefore, better understanding the relationship among different forage quality parameters can be useful to predict WSC in forage. The aforementioned equation may be useful for estimating WSC, with forage ADF, ash, and P concentration being useful predictors of WSC.

\section{Conclusions}

Accumulations of WSC in forages are important to determine forage utilization by ruminants. In this study, WSC was greater in $C_{3}$ compared to $C_{4}$ grasses. Diurnal changes affected WSC with greater WSC concentrations occurring at $1100 \mathrm{~h}$ and in late hours of the day compared to forages collected at $800 \mathrm{~h}$. Applications of poultry litter increased orchardgrass forage mass, although it did not affect forage WSC concentrations regardless of photosynthetic pathway. There were positive correlations between WSC and forage $\mathrm{K}, \mathrm{P}, \mathrm{Mn}$, and yield. When all forage quality measures and mineral content in forage were included in regression models, forage ADF, ash, and P content were the most useful predictors of WSC in forage and may be used as a proxy for WSC determinations. These results may be useful for identifying optimum harvest dates and times or help explain grazing preferences in mid-South silvopastoral systems.

Author Contributions: Conceptualization, A.J.A.; methodology, C.N. and M.A.; formal analysis, V.N. and M.A.; data curation, L.M. and M.A.; writing-original draft preparation, K.P.C. and C.N.; writing-review and editing, T.J.S., D.P., and C.N. All authors have read and agreed to the published version of the manuscript.

Funding: This research received no external funding.

Institutional Review Board Statement: Not applicable.

Informed Consent Statement: Not applicable. 
Data Availability Statement: Data will be made available upon publication.

Acknowledgments: Trade names or commercial products mentioned in this article is solely for the purpose of providing specific information, and do not infer either recommendation or endorsement by the U.S. Department of Agriculture. Authors are grateful for Taylor Adams with the USDA, Agricultural Research Service and Robert Rhine with the University of Arkansas for their oversight and coordination of the study site and assistance with sample collection and treatment implementation.

Conflicts of Interest: The authors declare no conflict of interest.

\section{References}

1. Orr, R.; Penning, P.; Harvey, A.; Champion, R. Diurnal patterns of intake rate by sheep grazing monocultures of ryegrass or white clover. Appl. Anim. Behav. Sci. 1997, 52, 65-77. [CrossRef]

2. Fisher, D.S.; Mayland, H.F.; Burns, J.C. Variation in ruminants' preference for tall fescue hays cut either at sundown or at sunup. J. Anim. Sci. 1999, 77, 762-768. [CrossRef] [PubMed]

3. Leury, B.J.; Siever-Kelly, C.; Simpson, R.J.; Gatford, K.L.; Dove, H. Spray-topping annual grass pasture with glyphosate to delay loss of feeding value during summer. IV. Diet composition, herbage intake, and performance in grazing sheep. Aust. J. Agric. Res. 1999, 50, 487-496. [CrossRef]

4. Ciavarella, T.A.; Dove, H.; Leury, B.J.; Simpson, R.J. Diet selection by sheep grazing Phalaris aquatica L. pastures of differing water-soluble carbohydrate content. Aust. J. Agric. Res. 2000, 51, 757. [CrossRef]

5. Horadagoda, A.; Fulkerson, W.J.; Nandra, K.S.; Barchia, I.M. Grazing preferences by dairy cows for 14 forage species. Anim. Prod. Sci. 2009, 49, 586-594. [CrossRef]

6. Burner, D.M.; Belesky, D.P. Diurnal Effects on Nutritive Value of Alley-Cropped Orchardgrass Herbage. Crop. Sci. 2004, 44, 1776-1780. [CrossRef]

7. Houx, J.H.; Garrett, H.E.; McGraw, R.L.; Iii, J.H.H. Applications of black walnut husks can improve orchardgrass and red clover yields in silvopasture and alley cropping plantings. Agrofor. Syst. 2008, 73, 181-187. [CrossRef]

8. Kingery, W.L.; Wood, C.W.; Delaney, D.P.; Williams, J.C.; Mullins, G.L.; Van Santen, E. Implications of Long-Term Land Application of Poultry Litter on Tall Fescue Pastures. J. Prod. Agric. 1993, 6, 390-395. [CrossRef]

9. Pederson, G.A.; Brink, G.E.; Fairbrother, T.E. Nutrient Uptake in Plant Parts of Sixteen Forages Fertilized with Poultry Litter. Agron. J. 2002, 94, 895-904. [CrossRef]

10. Barnes, R.F.; Nelson, C.J.; Moore, K.J.; Collins, M. The Science of Grassland Agriculture, 6th ed.; Wiley-Blackwell: Ames, IA, USA, 2007; pp. 341-411.

11. Jacobs, J.; Rigby, S.; McKenzie, F.; Ryan, M.; Ward, G.; Burch, S. Effect of nitrogen on pasture yield and quality for silage in Western Victoria. In Proceedings of the Australian Agronomy Conference, Perth, Australia, 24-29 September 1989; pp. $29-32$.

12. Kagan, I.A.; Anderson, M.L.; Kramer, K.J.; Seman, D.H.; Lawrence, L.M.; Smith, S.R. Seasonal and Diurnal Variation in WaterSoluble Carbohydrate Concentrations of Repeatedly Defoliated Red and White Clovers in Central Kentucky. J. Equine Vet. Sci. 2020, 84, 102858. [CrossRef]

13. Souza, A.; Sandrin, C.Z.; A Calió, M.F.; Meirelles, S.T.; Pivello, V.R.; Figueiredo-Ribeiro, R.C.L. Seasonal variation of soluble carbohydrates and starch in Echinolaena inflexa, a native grass species from the Brazilian savanna, and in the invasive grass Melinis minutiflora. Braz. J. Biol. 2010, 70, 395-404. [CrossRef]

14. Griggs, T.C.; Macadam, J.W.; Mayland, H.F.; Burns, J.C. Nonstructural Carbohydrate and Digestibility Patterns in Orchardgrass Swards during Daily Defoliation Sequences Initiated in Evening and Morning. Crop. Sci. 2005, 45, 1295-1304. [CrossRef]

15. Huntington, G.B.; Burns, J.C. Afternoon harvest increases readily fermentable carbohydrate concentration and voluntary intake of gamagrass and switchgrass baleage by beef steers12. J. Anim. Sci. 2007, 85, 276-284. [CrossRef]

16. Soil Survey Staff. Major Land Resource Areas. USDA-NRCS; 2019. Available online: https://data.nal.usda.gov/dataset/majorland-resource-areas-mlra (accessed on 10 September 2019).

17. Defauw, S.L.; Brye, K.R.; Sauer, T.J.; Hays, P. Hydraulic and Physiochemical Properties of a Hillslope Soil Assemblage in the Ozark Highlands. Soil Sci. 2014, 179, 107-117. [CrossRef]

18. Sauer, T.J.; Coblentz, W.K.; Thomas, A.L.; Brye, K.R.; Brauer, D.K.; Skinner, J.V.; Van Brahana, J.; Defauw, S.L.; Hays, P.D.; Moffitt, D.C.; et al. Nutrient cycling in an agroforestry alley cropping system receiving poultry litter or nitrogen fertilizer. Nutr. Cycl. Agroecosyst. 2014, 101, 167-179. [CrossRef]

19. Thomas, A.L.; Brauer, D.K.; Sauer, T.J.; Coggeshall, M.V.; Ellersieck, M.R. Cultivar influences early rootstock and scion survival of grafted black walnut. Am. Pomol. Soc. 2008, 62, 3-12.

20. Soil Survey Staff. Web Soil Survey. USDA-NRCS. 2019. Available online: https://websoilsurvey.sc.egov.usda.gov/App/ WebSoilSurvey.aspx (accessed on 10 September 2019).

21. National Climatic Data Center (NCDC); National Oceanic and Atmospheric Administration. Data Tools: Local Climatological Data (LCD). 2019. Available online: https:/ / www.ncdc.noaa.gov/cdo-web/datatools/lcd (accessed on 10 September 2019).

22. Van Soest, P.J.; Robertson, J.B. Systems of analysis for evaluating fibrous feeds. In Standardization of Analytical Methodology for Feeds: Proceedings of the International Workshop, Ottawa, ON, Canada, 12-14 March 1979; International Development Research Center: Ottowa, ON, Canada, 1980; pp. 49-60. 
23. AOAC. Official Methods of Analysis, Association of Official Analytical Chemists International, 17th ed.; AOAC International: Gaithersburg, MD, USA, 2000.

24. Dubois, M.; Gilles, K.A.; Hamilton, J.K.; Rebers, P.A.; Smith, F. Colorimetric Method for Determination of Sugars and Related Substances. Anal. Chem. 1956, 28, 350-356. [CrossRef]

25. SAS Institute Inc. SAS 9.2; SAS Institute Inc.: Cary, NC, USA, 2009.

26. Gomez, E.V.; Schaalje, G.B.; Fellingham, G.W. Performance of the Kenward-Roger Method when the Covariance Structure is Selected Using AIC and BIC. Commun. Stat. Simul. Comput. 2005, 34, 377-392. [CrossRef]

27. Saxton, A.M. A macro for converting mean separation output to letter groupings in Proc Mixed. In Proceedings of the 23rd SAS Users Group International, Cary, NC, USA, 22-25 March 1998; pp. 1243-1246.

28. Dickerson, J.; Burgdorf, D.; Bush, T.; Miller, C.; Wark, B.; Maher, R.; Poole, B. Vegetating with Native Grasses in Northeastern North America; United States Department of Agriculture Natural Resources Conservation Service \& Ducks Unlimited Canada: Washington, DC, USA, 1997.

29. Kuoppala, K.; Ahvenjärvi, S.; Rinne, M.; Vanhatalo, A. Effects of feeding grass or red clover silage cut at two maturity stages in dairy cows. 2. Dry matter intake and cell wall digestion kinetics. J. Dairy Sci. 2009, 92, 5634-5644. [CrossRef] [PubMed]

30. Weraduwage, S.M.; Chen, J.; Anozie, F.C.; Morales, A.; Weise, S.E.; Sharkey, T.D. The relationship between leaf area growth and biomass accumulation in Arabidopsis thaliana. Front. Plant Sci. 2015, 6, 167. [CrossRef]

31. Guanter, L.; Zhang, Y.; Jung, M.; Joiner, J.; Voigt, M.; Berry, J.A.; Frankenberg, C.; Huete, A.R.; Zarco-Tejada, P.; Lee, J.-E.; et al. Global and time-resolved monitoring of crop photosynthesis with chlorophyll fluorescence. Proc. Natl. Acad. Sci. USA 2014, 111, E1327-E1333. [CrossRef]

32. Azcon-Bieto, J.; Lambers, H.; Day, D.A. Effect of Photosynthesis and Carbohydrate Status on Respiratory Rates and the Involvement of the Alternative Pathway in Leaf Respiration. Plant Physiol. 1983, 72, 598-603. [CrossRef]

33. Wehr, R.; Munger, J.W.; McManus, J.B.; Nelson, D.D.; Zahniser, M.S.; Davidson, E.A.; Wofsy, S.C.; Saleska, S.R. Seasonality of temperate forest photosynthesis and daytime respiration. Nat. Cell Biol. 2016, 534, 680-683. [CrossRef]

34. Cajarville, C.; Britos, A.; Errandonea, N.; Gutiérrez, L.; Cozzolino, D.; Repetto, J. Diurnal changes in water-soluble carbohydrate concentration in lucerne and tall fescue in autumn and the effects on in vitro fermentation. N. Z. J. Agric. Res. 2015, 58, 281-291. [CrossRef]

35. Clark, J.K.; Shanks, B.C.; Jogan, K.S.; Philipp, D.; Coffey, K.P.; Jack, N.E.; Caldwell, J.D.; Rhein, R.T. Effects of forage species and poultry litter application timing on forage preference by horses. J. Anim. Sci. 2016, 94, 4985-4992. [CrossRef]

36. Wilson, J.R.; Minson, D.J. Prospects for improving the digestibility and intake of tropical grasses. Trop. Grassl. 1980, 14, $253-259$.

37. Mayland, H.F.; Shewmaker, G.E.; Harrison, P.A.; Chatterton, N.J. Nonstructural Carbohydrates in Tall Fescue Cultivars: Relationship to Animal Preference. Agron. J. 2000, 92, 1203-1206. [CrossRef]

38. Nelson, C.J. Apparent respiration and plant productivity. In Physiology and Determination of Crop Yield; Boote, K.J., Bennett, J.M., Sinclair, T.R., Paulsen, G.M., Eds.; American Society of Agronomy: Madison, WI, USA, 1994; pp. 251-258.

39. Jensen, K.B.; Harrison, P.; Chatterton, N.J.; Bushman, B.S.; Creech, J.E. Seasonal Trends in Nonstructural Carbohydrates in Cooland Warm-season Grasses. Crop. Sci. 2014, 54, 2328-2340. [CrossRef]

40. Garrett, H.; Kerley, M.; Ladyman, K.; Walter, W.; Godsey, L.; Van Sambeek, J.; Brauer, D. Hardwood silvopasture management in North America. Agrofor. Syst. 2004, 61, 21-33. [CrossRef]

41. Lin, C.H.; McGraw, R.L.; George, M.F.; Garrett, H.E. Shade effects on forage crops with potential in temperate agroforestry practices. Agrofor. Syst. 1998, 44, 109-119. [CrossRef]

42. Denison, R.F.; Perry, H.D. Seasonal Growth Rate Patterns for Orchardgrass and Tall Fescue on the Appalachian Plateau. Agron. J. 1990, 82, 869-873. [CrossRef]

43. Waramit, N.; Moore, K.J.; Heggenstaller, A.H. Composition of Native Warm-Season Grasses for Bioenergy Production in Response to Nitrogen Fertilization Rate and Harvest Date. Agron. J. 2011, 103, 655-662. [CrossRef]

44. Brink, G.E.; Sistani, K.R.; Oldham, J.L.; Pederson, G.A. Maturity Effects on Mineral Concentration and Uptake in Annual Ryegrass. J. Plant Nutr. 2006, 29, 1143-1155. [CrossRef]

45. Schlegel, P.; Wyss, U.; Arrigo, Y.; Hess, H. Mineral concentrations of fresh herbage from mixed grassland as influenced by botanical composition, harvest time and growth stage. Anim. Feed Sci. Technol. 2016, 219, 226-233. [CrossRef]

46. Halgerson, J.L.; Sheaffer, C.C.; Martin, N.P.; Peterson, P.R.; Weston, S.J. Near-infrared reflectance spectroscopy prediction of leaf and mineral concentrations in alfalfa. J. Agron. 2004, 96, 344-351. [CrossRef]

47. Morris, R.J.; Fox, R.H.; Jung, G.A. Growth, P. Uptake, and Quality of Warm and Cool-Season Grasses on a Low Available P Soil1. Agron. J. 1982, 74, 125-129. [CrossRef]

48. Minson, D.J. Forage quality: Assessing the plant-animal complex. In Proceedings of the 14th International Grassland Congress, Lexington, Kentucky, 15-24 June 1981; Smith, J.A., Hays, V.W., Eds.; Westview Press Inc.: Boulder, CO, USA, 1981 ; p. 23.

49. Follett, R.F.; Wilkinson, S.R. Nutrient management of forages. In An Introduction to Grassland Agriculture, 5th ed.; Barnes, R.F., Miller, D.A., Nelson, C.J., Eds.; Iowa State University Press: Ames, IA, USA, 1995; Volume 1, p. 55.

50. Baker, B.S.; Reid, R.L. Mineral Concentrations of Forage Species Grown in Central West Virginia on Various Soil Series; Bulletin Number 657; West Virginia University Agricultural and Forestry Experiment Station: Morgantown, WV, USA, 1977. 
51. Chatterton, N.J.; Watts, K.A.; Jensen, K.B.; Harrison, P.A.; Horton, W.H. Nonstructural Carbohydrates in Oat Forage. J. Nutr. 2006, 136, 2111S-2113S. [CrossRef] [PubMed]

52. Wang, P.; Souma, K.; Okamoto, H.; Kin, S.; Sugita, A.; Furudate, A.; Sato, C.; Nibe, A.; Cai, Y.; Masuko, T. Effects of Potassium Fertilizer on Water-Soluble Carbohydrate Content of Timothy (Phleum pratense L.), Silage Fermentation, Nutritive Values, and Nutrient Intake. Am. J. Plant Sci. 2014, 5, 1030-1038. [CrossRef] 